Tarasevich Tatyana,

Associate Professor, Kyiv University of Law of the NASU of Ukraine,

7A, Dobrohotova str., Kyiv, 03142, Ukraine

ORCID: 0000-0002-3860-9909

Kortukova Tamara,

Senior Lecturer, Kyiv University of Law of the NASU of Ukraine

7A, Dobrohotova str., Kyiv, 03142, Ukraine

ORCID: 0000-0002-3376-0159

\title{
LEGAL REGULATION OF THE COMBATING ILLEGAL MIGRATION WITHIN THE EUROPEAN UNION
}

The article analyzes legal regulation of the combating illegal migration within the European Union on the supernational level. It gives definition and reveals the main elements of illegal migration. In the context of the European migrant crises, which started in 2015, the article analyses the main reasons of this phenomenon and differentiates the main routs of illegal migrants to the EU.

Key words: migration; combating illegal migration; EU acquit; European migrant crises.

Тарасевич Тетяна, Кортукова Тамара. Правове регулювання боротьби з нелегальною міграцією в Свропейському Союзі.

У статті проаналізовано правове регулювання боротьби з нелегальною міграиією в межах Європейського Союзу на наднаціональному рівні. Подається визначення та розкриваються основні елементи нелегальної міграції. У контексті Європейських міграційних криз, які розпочалися у 2015 році, у статті проаналізовано основні причини иього явища та розмежовано основні маршрути нелегальних мігрантів до ЄС.

Ключові слова: мігращія; боротьба з нелегальною мігращуією; протидія $Є C$; Європейська міграиійна криза.

Relevance of research topic. Nowadays in the modern globalized world, the issue of the combating illegal migration is in the top priorities of the world community agenda. Military conflicts, such as the events of the Arab Spring, the low standard of living, and the economic instability of some Asian and African countries have led people to seek safety and better living conditions, particularly moving to the EU Member States. 
According to Eurostat data, in 2017 in three EU countries, namely France, Germany and Greece were detected 339,000 illegally resided third-country nationals. According to UN Refugee Statistics, 362,000 refugees and migrants risked their lives crossing the Mediterranean in 2016 (7). In the first half of 2017, more than 105,000 refugees and migrants came to Europe. However, in the beginning of 2017, over 2,700 people died or disappeared during the crossing of the Mediterranean to reach Europe (12).

In addition, the problem of illegal migration has intensified the resumption of checks at EU internal borders; demonstrated the lack of solidarity and the inability of EU Member States to negotiate with each other; revealed imperfection in the legislation to regulate the problem; has in some way caused the UK's exit from the $\mathrm{EU}$, the so-called Brexit; and furthermore jeopardized the functioning of the whole EU. Taking into consideration the abovementioned, it is extremely important to find comprehensive approaches to combat illegal migration in the EU.

Materials. The issue of the combating illegal migration within the European Union were analyzed by such scholars as J. Gour, C. Morehaus, M. Blomfield, D. Popescu. M. Provera made a research on the criminalisation of irregular migration in the European Union. D. Beseda analized migration crisis in the EU and its impact on the security situation in Ukraine.

Results. The concept of illegal migration was developed by the EU Commission and recorded in the 2006 in the Communication from the Commision on Policy priorities in the fight against illegal immigration of third-country nationals [1]. Accordingly, illegal migration means the illegal crossing of the territory of EU Member States by land, sea or air, including the transit zones of airports by thirdcountry nationals. Such an intersection occurs through the use of forged documents or through organized criminal groups of smugglers and traffickers. Illegal immigrants also include persons who crossed the border legally with a valid visa or visa-free regime, but exceeded their stay or changed their purpose of stay without the consent of the authorities; as well as asylum seekers who did not leave the country after refusal.

In particular, $\mathrm{K}$. Morehous and $\mathrm{M}$. Blomfield identify 8 conditions under which third-country nationals may be considered illegal immigrants: «1) illegal border crossing; 2) entry with invalid documents; 3) entry with forged documents; 4) stay longer than a visa or temporary residence permit; 5) loss of status due to non-renewal of temporary residence permit or violation of citizenship conditions; 6) born of illegal immigrants; 7) escape during the asylum procedure or after a negative decision on asylum has not left the country; 8) failure by the State to return for legal or practical reasons» $(9$, p. 4$)$.

D. Popescu notes that «the phenomenon of illegal migration is viewed from the point of view of the destination countries, often linking illegal migration with entry, stay or illegal work in the country, which means that the migrant does not have the necessary permits or necessary documents, concerning entry, stay and/or work in the country concerned. In any case, the illegality of migration may also occur in one's 
home country, for example, when a person crosses a border without a passport or valid travel document or they do not meet the requirements of leaving the country concerned» $(10)$.

Thus, three groups of illegal migrants can be identified: persons who crossed the border illegally; persons who have exceeded their stay or changed their purpose of stay without the consent of the authorities; and asylum seekers who did not leave the country after refusing asylum.

J. Gour distinguishes between irregular migration and illegal migration, noting that EU documents use the term «irregular» as well as «illegal». However, in her opinion, the term «illegal» has a negative connotation (8). M.Provera notes that «in the context of the EU, the term illegal migration is used in the sense that the presence of a person in the territory of a Member State is contrary to law $(11, \mathrm{p} .4) »$. In the article we will use the term «illegal migration», which means a violation of the law when entering or staying in the territory of an EU Member State.

Illegal migration may include the presence of an intermediary, a smuggler who organizes a border crossing. In this case, this phenomenon will be called human smuggling, but if the movement of people is entirely voluntary without assistance, it will be illegal entry.

In addition, there is the phenomenon of human trafficking as the most serious type of illegal migration. Trafficking in human beings is interrelated with other forms of organized crime and is considered a crime against a person.

O. Potemkin has identified such major ways of illegal immigration to the EU as: «1) The North and West African coasts are the most massive means of transporting illegal immigrants to the EU; from African countries they come to Italy, Malta and Spain; 2) the East Mediterranean direction; the ultimate goal on this route is Greece; Turkey and Middle Eastern countries are in transit; 3) the Balkan route passes through the Western Balkan states; further, immigrants enter the EU through Greece, Italy, Slovenia, Austria, Bulgaria, Romania and Hungary; 4) The Central and Eastern European route is transited through Russia, Ukraine, Moldova and Belarus, from here through Poland, the Czech Republic, Slovakia, Hungary, Bulgaria and Romania to the territory of the EU Central Countries; 5) Baltic route - organized illegal immigration through the Baltic countries to Scandinavia» (15).

D. Beseda distinguishes the Eastern Mediterranean Route (Turkey - Aegean Sea - Greece or from Turkey to Greece by land) among the main routes of illegal migrants heading to the EU; Central Mediterranean Route (Libya or Tunisia - Italy); Western Mediterranean Route (Morocco or Algeria - Spain). At the same time, the largest number of migrants arrived in the EU via the Central Mediterranean Route in $2017-119369$, which is $34 \%$ less than in 2016. The main countries of origin of migrants arriving on this route in 2017 were Nigeria (15\%), Guinea (8\%) and Côte d'Ivoire (8\%) (14, p. 299). 
There are also the land, maritime and air routes of illegal migrants. Land includes the route through Turkey to Bulgaria, as well as from Morocco to Spain, through the cities of Ceuta and Melilla. Regarding maritime routes, Greece, Spain, Italy, Malta are most often affected by illegal migrants countries. In addition, illegal migrants travel to the EU by air, falsifying documents. Thus, the countries located at the EU's external borders suffer most from illegal immigration, in particular Greece, Spain, Italy and Malta.

In order to combat illegal migration and trafficking in human beings, some legislation has been developed in the EU and provides for a series of measures to be taken to counteract illegal entry, residence of illegal migrants and their employment.

However, the negative aspects of illegal migration are still present in the EU, in particular, a threat to national security; it is a potential source of criminal activity; implies epidemiological risks; tends to exacerbate ethnic conflicts in society. In addition, illegal immigrants are excluded from the system of employment, taxation and social protection, and states can not keep records of these people.

The legal basis for combating illegal migration in the EU is:

Directive 2001/5 on the liability of carriers (2). Accordingly, carriers should ensure that third-country nationals who intend to enter the territory of EU Member States have the necessary travel documents and visas if necessary. In addition, EU Member States are required to impose financial penalties on carriers that have breached their obligations. They are obliged to ensure that: the maximum fine is at least 5,000 euros; a minimum fine of at least EUR 3,000; the maximum amount of the fine imposed as a lump sum for each violation was not less than EUR 500 thousand.

Directive 2002/90/EC (3), which provides for the promotion of unauthorized entry, transit and residence, criminalizes assistance in committing illegal immigration and residence.

Framework Decision 2002/946 (16) on the strengthening of punishment in order to prevent unauthorized entry, transit and residence establishes minimum rules on the punishment, liability of legal persons.

Council Directive 2004/81/EC (4) lays down the conditions for the granting of temporary residence permits to third-country nationals who have been victims of trafficking, and to those who assisted the smuggling of migrants as they cooperate with national authorities in identifying and prosecuting smugglers. The scope of the Directive extends to third-country nationals who have been victims of trafficking offenses, even if they have illegally entered the territory of the EU Member States and to persons who have facilitated illegal immigration. However, the Directive extends to third-country nationals who have reached the legal age of the Member State concerned, but Member States may decide to apply it to minors under the conditions laid down by their national law.

The Return Directive 2008/115/EC (5) obliges EU Member States to return illegal migrants or give them legal status. 
Directive 2009/52/EC (6) lays down sanctions and measures to be applied in the Member States in respect of employers of illegal third-country nationals. The directive prohibits any employment of illegal immigrants and provides for a number of sanctions. Employers are obliged to ensure that third-country nationals who work for them are legally resident in the territory of the Member State concerned and inform the competent authorities of the employment of legal migrants; employers pay penalties depending on the number of illegal immigrants employed and also cover the cost of their travel; employers of illegal immigrants are deprived of certain rights and privileges, such as the right to receive assistance and grants from public authorities, the right to participate in public procurement procedures, etc. Member States shall carry out inspections in order to comply with the directive.

However, the directive does not regulate the liability of illegal workers. Instead, this issue is regulated by Member States independently. However, the document contains a set of rules that protect the interests of immigrants. For example, employers are required to pay them full salaries and make other payments related to their employment, that is, taxes and benefits, as if they were legally employed.

In addition, in 2016, Regulation 2016/1953 on the creation of a European travel document for the return of illegally staying third-country nationals in the EU was adopted (13). Prior to that, a standard travel document for returning third-country nationals, introduced by a Council Recommendation of 30 November 1994, was in place in the EU. However, given its low security standards and not accepted by some third countries, the European Travel Document for Return of Citizens has been improved and unified. The enhanced security features and technical specifications of a European return document should facilitate its recognition by third countries.

Conclusion. To conclude, however the legislation has been developed in the EU to combat illegal migration, but the legislation in this area is quite extensive and needs to be further refined given the challenges of today. The proper regulation of illegal migration will influence on the integrity of the whole European Union.

\section{REFERENCES}

1. Communication from the Commision on Policy priorities in the fight against illegal immigration of third-country nationals. URL: http://www.agri-migration.eu/ docs/Commission_on_policy_priorities_illegal_immigration_of_tcn_2006.

2. Council Directive 2001/51/EC of 28 June 2001 supplementing the provisions of Article 26 of the Convention implementing the Schengen Agreement of 14 June 1985. URL: https://eur-lex.europa.eu/legal-content/EN/ALL/?uri=CELEX:32001L0051.

3. Council Directive 2002/90/EC of 28 November 2002 defining the facilitation of unauthorised entry, transit and residence. URL: https://eur-lex.europa.eu/legalcontent/EN/ALL/?uri=celex\%3A32002L0090. 
4. Council Directive 2004/81/EC of 29 April 2004 on the residence permit issued to third-country nationals who are victims of trafficking in human beings or who have been the subject of an action to facilitate illegal immigration, who cooperate with the competent authorities. UL: https://eur-lex.europa.eu/legal-content/EN/ALL/ ?uri=CELEX\%3A32004L0081.

5. Directive 2008/115/EC of the European Parliament and of the Council of 16 December 2008 on common standards and procedures in Member States for returning illegally staying third-country nationals. URL: https://eur-lex.europa.eu/ legal-content/EN/ALL/?uri=celex\%3A32008L0115.

6. Directive 2009/52/EC of the European Parliament and of the Council of 18 June 2009 providing for minimum standards on sanctions and measures against employers of illegally staying third-country nationals. URL: https://eur-lex.europa.eu/ legal-content/EN/TXT/?uri=CELEX:32009L0052.

7. Enforcement of immigration legislation statistics. URL: https://ec.europa.eu/ eurostat/statistics-explained/index.php?title=Enforcement_of_immigration_ legislation_statistics.

8. Gour J. EU Policies on Mixed Migration Flows in the Mediterranean Sea / Julia Gour // European Union Centre in Singapore. - 2015. - № 13. - P. 1-18.

9. Morehaus C. Irregular migration in Europe / C. Morehaus, M. Blomfield // Migration Policy Institute. - 2011. - P. 1-17.

10. Popescu Ljungholm D. Preventing Illegal Migration in Romania / Doina Popescu Ljungholm. // 149. - 2014. - P. 741-745.

11. Provera M. The Criminalisation of Irregular Migration in the European Union / Mark Provera. // CEPS. - 2015. - № 80. - P. 1-38.

12. UNHCR - URL: https://www.unhcr.org/europe-emergency.html.

13. Regulation (EU) 2016/1953 of the European Parliament and of the Council of 26 October 2016 on the establishment of a European travel document for the return of illegally staying third-country nationals, and repealing the Council Recommendation of 30 November 1994. URL: https://eur-lex.europa.eu/legal-content/EN/TXT/? qid=1565424408456\&uri=CELEX:32016R1953.

14. Beseda D. Mihratsiyna kryza $\mathrm{v}$ YES ta yiyi bezpechna sytuatsiya $\mathrm{v}$ Ukrayini. Dmytro Beseda // Pidpryyemstvo, hospodarstvo i pravoyu. - 2018. - № 12. S. 299-303.

15. Potemkina O. Yevropeys'kyy Soyuz $u$ borot'bi $z$ nelehal'noyu immihratsiyeyu: novi tendentsiyi [Elektronnyy resurs] / O. Potemkina. - 2009. Rezhym dostupu do resursu. URL: http://alleuropa.ru/index.php?option=com content\&task=view\&id=1130.

16. 2002/946/JHA: Council framework Decision of 28 November 2002 on the strengthening of the penal framework to prevent the facilitation of unauthorised entry, transit and residence. URL: https://eur-lex.europa.eu/legal-content/EN/ALL/?uri= CELEX\%3A32002F0946. 